\title{
PENGARUH KEPEMIMPINAN TRANSFORMASIONAL DAN KOMPENSASI TERHADAP KINERJA KARYAWAN PADA PERUSAHAAN BUMN DI KOTA PADANG
}

\author{
Sigit Sanjaya \\ Universitas Putra Indonesia "YPTK" \\ Sigit_Tendou_Sanjaya@yahoo.com
}

\begin{abstract}
Abstrak
Penelitian ini bertujuan untuk mengetahui: (1) Pengaruh kepemimpinan transformasional terhadap kinerja karyawan pada perusahaan BUMN di kota Padang (2) Pengaruh kompensasi terhadap kinerja karyawan pada perusahaan BUMN di Kota Padang. Penelitian ini menggunakan metode survei terhadap 30 kantor cabang BUMN di Kota Padang. Responden dalam peneltian ini yaitu manajer divisi. Jumlah responden yaitu 67 orang. Keseluruhan anggota populasi dijadikan sebagai sampel (total sampling). Hasil penelitian menunjukkan bahwa (1) Kepemimpinan transformasional berpengaruh signifikan positif terhadap kinerja karywan pada perusahaan BUMN di kota Padang (2) Kompensasi berpengaruh signifikan positif terhadap kinerja karyawan pada perusahaan BUMN di kota Padang. Bagi peneliti selanjutnya diharapkan dapat memperluas daerah penelitian, atau dengan melakukan perubahan sampel penelitian
\end{abstract}

Kata kunci: Kepemimpinan Transformasional, Kompensasi, Kinerja Karyawan

\section{PENDAHULUAN}

Setiap perusahaan memerlukan karyawan sebagai sumber daya manusia yang mempunyai peran vital sebagai penunjang kelancaran tugas dalam suatu perusahaan. Sebagai sumber daya manusia, karyawan merupakan aset terpenting dibandingkan dengan faktor produksi lainnya, yaitu sebagai penggerak utama berjalannya perusahaan. Di dalam diri setiap karyawan, terdapat berbagai perilaku ataupun sikap yang diiringi dengan berbagai kebutuhan yang ingin diwujudkannya. Oleh karena itu, perusahaan perlu memperhatikan perilaku dan kebutuhan-kebutuhan dari karyawan yang dimilikinya agar kinerja karyawan sesuai dengan harapan perusahaan.

Kinerja adalah hasil atau tingkat keberhasilan seseorang atau secara keseluruhan selama periode tertentu di dalam melaksanakan tugas dibandingkan dengan berbagai kemungkinan, seperti standar hasil kerja, target atau sasaran atau kriteria yang telah ditentukan terlebih dahulu dan telah disepakati bersama sebelumnya. Kinerja manajerial merupakan hasil dari proses aktivitas manajerial yang efektif mulai dari proses perencanaan, pelaksanaan, penatausahaan, laporan pertanggungjawaban, pembinaan, dan pengawasan (Basri \& Rivai, 2005). Menurut Donnelly, Gibson, dan Ivancevich dalam Basri \& Rivai (2005) "kinerja merujuk kepada tingkat keberhasilan dalam melaksanakan tugas serta kemampuan untuk mencapai tujuan yang telah ditetapkan.

Kinerja dalam menjalankan fungsinya tidak berdiri sendiri, tetapi berhubungan dengan kepuasan kerja dan tingkat imbalan, dipengaruhi oleh keterampilan, kemampuan dan sifat-sifat individu. Oleh karena itu menurut Donelly, Gibson dan Ivancevich dalam Basri \& Rivai (2005) kinerja individu pada dasarnya dipengaruhi oleh faktor-faktor: (a) harapan mengenai imbalan; (b) dorongan; (c) kemampuan; kebutuhan dan sifat; (d) persepsi terhadap tugas; (e) imbalan internal dan eksternal; (f) persepsi terhadap tingkat imbalan dan kepuasan kerja. Dengan demikian, kinerja pada dasarnya ditentukan oleh tiga hal, yaitu: (1) kemampuan, (2) keinginan dan (3) lingkungan. Oleh karena itu, agar mempunyai kinerja yang baik, seseorang harus mempunyai keinginan yang tinggi untuk mengerjakan serta mengetahui pekerjaannya.

Karyawan yang berkualitas adalah karyawan yang mempunyai kepemimpinan diri dan mampu membangun kepemimpinan tim. Kepemimpinan (leadership) adalah proses dimana seseorang atau sekelompok (tim) memainkan pengaruh atas orang (tim) lain, menginspirasikan, memotivasi dan mengarahkan aktivitas bersama untuk mencapai sasaran dan tujuan bersama. Sumber daya yang 
dimiliki tidak dapat digunakan untuk mencapai tujuan perusahaan jika tidak dikelola dengan baik, sehingga peranan kepemimpinan disini sangat penting untuk dapat mengelola sumber daya yang ada dengan baik berdasarkan wewenangnya. Dasarnya kepemimpinan merupakan gaya seorang pemimpin mempengaruhi bawahannya agar mau bekerja sama dan bekerja efektif sesuai dengan perintahnya.

Kompensasi bagi karyawan merupakan salah satu faktor penting yang menjadi pendorong dalam bekerja yang pada akhirnya akan mempengaruhi motivasi kerja karyawan untuk meningkatkan kinerja. Karyawan yang tidak merasa puas dengan kompensasi yang di berikan perusahaan akan rendah kinerjanya oleh karena itu sangat penting bagi perusahaan untuk mengembangkan program-program kompensasi. Untuk meningkatkan dan mempertahankan kinerja karyawan perusahaan dituntut untuk lebih serius dalam hal penentuan kompensasi yang akan di berikan kepada karyawannya. Jika karyawan merasa puas dengan kompensasi yang mereka peroleh dari perusahaan, maka mereka akan berusaha lebih baik untuk melaksanakan dan menyelesaikan pekerjaannya. Ketika gaya kepemimpinan transformasional dan pemberian kompensasi berjalan dengan lancar dan sesuai dengan perencanaannya maka tahapan selanjutnya yang diharapkan akan terjadi adalah peningkatan kinerja karyawan. Ketika kinerja karyawan telah tercapai maka perusahaan dapat mengukur sejauh mana peningkatan kinerja yang mereka capai.

\section{KAJIAN LITERATUR}

\section{A. Kinerja Karyawan}

Kinerja adalah hasil atau tingkat keberhasilan seseorang secara keseluruhan atau kelompok selama periode tertentu di dalam melaksanakan tugas dibandingkan dengan berbagai kemungkinan, seperti standar hasil kerja, target atau sasaran atau kriteria yang telah ditentukan terlebih dahulu dan telah disepakati bersama sebelumnya (Basri \& Rivai, 2005).

Menurut Rai (2008) kinerja merupakan hasil evaluasi terhadap pekerjaan yang telah dilakukan dan dibandingkan dengan kriteria yang ditetapkan bersama. Sedangkan menurut Sedarmayanti (2004, dalam Syaiin 2008) mengemukakan kinerja (performance) merupakan hasil kerja yang dicapai oleh seseorang atau kelompok dalam suatu organisasi sesuai dengan wewenang dan tanggung jawab masing-masing dalam upaya mencapai tujuan organisasi yang bersangkutan secara legal dan tidak melanggar hukum dan tidak bertentangan dengan moral ataupun etika.

Menurut Mangkunegara (2010) kinerja adalah prestasi kerja atau hasil kerja (output) baik kualitas maupun kuantitas yang dicapai sumber daya manusia persatuan periode waktu dalam melaksanakan tugas kerjanya sesuai dengan tanggung jawab yang diberikan kepadanya. Robbins (2008) mendefinisikan kinerja yaitu suatu hasil yang dicapai oleh karyawan dalam pekerjaannya menurut kriteria tertentu yang berlaku untuk suatu pekerjaan. Mengukur tingkat kinerja karyawan biasanya menggunakan performance system yang dikembangkan melalui pengamatan yang dilakukan oleh atasan masing-masing unit kerja dengan beberapa alternatif cara penilaian maupun dengan wawancara langsung dengan karyawan yang bersangkutan. Informasi yang diperoleh dari penilaian kinerja tersebut dapat digunakan lagi bagi penyelia atau manajer untuk mengelola kinerja karyawan, melalui apa penyebab kelemahan maupun keberhasilan dari kinerja karyawan sehingga dapat digunakan sebagai pertimbangan untuk menentukan target maupun langkah perbaikan selanjutnya untuk mencapai tujuan perusahaan.

Manfaat penilaian kinerja bagi semua pihak adalah agar bagi mereka mengetahui manfaat yang dapat mereka harapkan (Basri \& Rivai, 2005). Adapaun orang-orang yang berkepentingan dalam penilaian tersebut adalah: 1) Individu yang dinilai 2) Penilai (atasan, supervisor, pimpinan, manajer, konsultan) 3) Perusahaan. Manfaat bagi karyawan yang dinilai dalam penilaian kinerja: 1) Meningkatkan motivasi. 2) Meningkatkan kepuasan hidup. 3) Adanya kejelasan standar dari hasil yang ditetapkan 4) Umpan balik dari kinerja lalu yang kurang atraktif dan konstruktif 5) Pengetahuan tentang kekuatan dan kelemahan menjadi lebih besar, membangun kekuatan dan mengurangi kelemahan seminimal mungkin 6) Adanya pandangan yang jelas tentang konteks pekerjaan 7) Peningkatan pengertian tentang nilai pribadi 8) Kesempatan untuk mendiskusikan masalah pekerjaan dan solusinya. Manfaat penilaian kinerja penilai dalam (Rivai \&Basri, 2005) yaitu : 1) Kesempatan untuk mengukur dan mengidentifikasikan kecenderungan kinerja karyawan untuk perbaikan manajemen selanjutnya. 2) Kesempatan untuk mengembangkan suatu pandangan umum tentang pekerjaan individu dan departemen yang lengkap. Indikator kinerja karyawan menurut Robbins (2008) yaitu: 1) Kualitas kerja 2) Kuantitas kinerja 3) Ketepatan waktu 4) Efektivitas 5) Kemandirian. 


\section{B. Kepemimpinan Transformasional}

Rivai (2012) gaya kepemimpinan adalah pola menyeluruh dari tindakan seorang pemimpin baik yang tampak maupun yang tidak tampak oleh bawahannya. Menurut Tjiptono (2006) gaya kepemimpinan merupakan suatu cara yang digunakan pemimpin untuk berinteraksi dengan bawahannya Kepemimpinan transformasional digambarkan sebagai gaya kepemimpinan yang dapat membangkitkan atau memotivasi pengikut, sehingga dapat berkembang dan mencapai kinerja pada tingkat yang tinggi. Pemimpin yang transformasional harus mampu mengajak bawahannya untuk melakukan perubahan dimana hal tersebut berpengaruh terhadap kinerja dari karyawan itu sendiri.

Gaya pemimpin transformasional mencurahkan perhatian pada hal-hal dan kebutuhan pengembangan masing-masing pengikut. Pemimpin transformasional mengubah kesadaran para pengikut akan persoalan-persoalan dengan membantu mereka memandang masalah lama dengan caracara baru, dan mereka mampu membangkitkan dan mengilhami para pengikut untuk mengeluarkan upaya ekstra demi mencapai sasaran kelompok.

Kepemimpinan transformasional meningkatkan motivasi, moral dan kinerja pengikut melalui berbagai mekanisme. Ini termasuk menghubungkan identitas diri pengikut dengan misi dan indentitas kolektif organisasi; menjadi panutan bagi pengikutnya yang menginspirasi mereka; menantang pengikut untuk mengambil kepemilikan yang lebih besar dalam pekerjaan mereka, dan memahami kekuatan beserta kelemahan pengikut, sehingga pemimpin dapat menyelaraskan pengikut dengan tugas-tugas yang mengoptimalkan kinerja mereka.

Pemimpin transformasional menginspirasi, menyalurkan energi, dan merangsang pengikut secara intelektual untuk mencapai kinerja yang tinggi. Melalui pelatihan, para manajer ataupun calon atasan dapat belajar teknik dan mendapatkan kualitas yang mereka butuhkan untuk menjadi pemimpin transformasional. Kepemimpinan transformasional ini berpusat pada asumsi bahwa para pemimpin dapt merubah keyakinan, asumsi dan perilaku pengikut dengan menekankan pentingnya kolektif ataupun tujuan organisasi. Kepemimpinan transformasional mengacu pada pemimpin yang berhasil menggerakkan pengikut melampaui kepentingan diri secara langsung melalui pengaruh ideal, inspirasi, stimulasi intelektual ataupun pertimbangan intelektual. Menurut Mamik (2010) indikator kepemimpinan transformasional yaitu: 1) orientasi tugas 2) orientasi hubungan 3) kekuasaan jabatan.

\section{Kompensasi}

Kompensasi adalah semua pendapatan yang berbentuk uang, barang langsung atau tidak langsung yang diterima karyawan sebagai imbalan atas jasa yang diberikan kepada karyawan (Hasibuan: 2006). Menurut Simamora (2006) kompensasi dapat dibagi menjadi kompensasi langsung (direct compensation) dan kompensasi tidak langsung (indirect compensation). Kompensasi finansial langsung (direct financial compensation) terdiri dari bayaran (pay) yang diperoleh dalam bentuk gaji, upah dan bonus. Kompensasi finansial tidak langsung (indirect financial compensation) yang disebut tunjangan meliputi semua imbalan finansial yang tidak tercakup dalam kompensasi langsung. Kompensasi non finansial (non financial compensation) terdiri dari kepuasan kerja yang diperoleh seseorang dari pekerjaan itu sendiri atau dari lingkungan psikologis dimana karyawan tersebut bekerja.

Para karyawan mungkin akan menghitung kinerja dan pengorbanan dirinya dengan kompensasi yang diterima. Apabila karyawan merasa tidak puas dengan kompensasi yang didapat, dia dapat mencoba mencari pekerjaan lain yang memberi kompensasi lebih baik. Kompensasi yang baik akan memberikan efek positif bagi perusahaan, dimana mendapatkan karyawan yang berkualitas baik, memacu karyawan untuk bekerja lebih giat dan meraih prestasi.

Kompensasi merupakan hal yang rumit, karena didalamnya melibatkan dasar yang layak, rasional, logika dan dapat dipertanggungjawabkan serta menyangkut faktor emosional dari aspek tenaga kerja. Kompensasi merupakan salah satu faktor krusial bagi kelangsungan kerja karyawan di perusahaan yang berpengaruh pada kepuasan kerja, loyalitas atau aspek kerja lainnya. Pendorong utama keterikatan karyawan di perusahaan adalah fokus kepada pelanggan. Kompensasi dan benefit serta komunikasi. Kompensasi diberikan dengan tujuan memberikan rangsangan dan motivasi pada karyawan untuk meningkatkan prestasi kerja, serta efisiensi dan efektivitas produksi. Oleh karena itu, bila kompensasi diberikan dengan benar, para karyawan akan lebih terpuaskan dan termotivasi untuk mencapai sasaran-sasaran organisasi. Akan tetapi, jika para karyawan memandang kompensasi mereka tidak memadai, prestasi kerja, motivasi dan kepuasan kerja mereka bisa turun secara drastis karena 
kompensasi merupakan hal krusial bagi karyawan. Indikator kompensasi menurut Hasibuan (2012) yaitu: 1) Gaji 2) Upah 3) Upah insentif 4) Asuransi 5) Fasilitas kantor.

\title{
D. Kerangka Konseptual
}

Berdasarkan tinjauan teori penelitian terdahulu dan landasan teori serta permasalahan yang telah dikemukakan, maka digambarkan kerangka konseptual sebagai berikut:

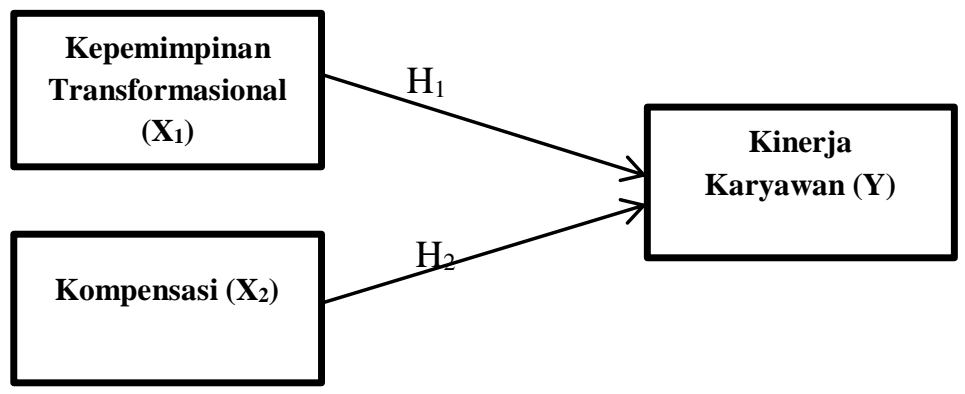

\section{Gambar 1 \\ Kerangka Konseptual}

\begin{abstract}
Hipotesis
Adapun hipotesis dalam penelitian ini adalah sebagai berikut:

$\mathrm{H}_{1}$ : Kepemimpinan transformasional berpengaruh signifikan postif terhadap kinerja karyawan

$\mathrm{H}_{2}$ : Kompensasi berpengaruh signifikan positif terhadap kinerja karyawan
\end{abstract}

\section{METODE PENELITIAN}

Jenis penelitian ini adalah penelitian kausatif yaitu untuk melihat pengaruh sebab akibat bagaimana variabel independen mempengaruhi variabel dependen dengan menggunakan metode kuantitatif. Dalam penelitian ini melihat seberapa jauh pengaruh kepemimpinan transformasional dan kompensasi terhadap kinerja karyawan. Populasi dalam penelitian ini yaitu manajer divisi perusahaan BUMN di kota Padang yang direncanakan berjumlah 120 orang, namun kuesioner yang kembali berjumlah 67 kuesioner. Teknik pengambilan sampel yaitu menggunakan (total sampling) dimana keseluruhan anggota populasi dijadikan sebagai sampel penelitian.

Jenis data yang dipakai dalam penelitian ini adalah data subyek (self-report data). Data subyek adalah jenis data penelitian yang berupa opini, sikap, pengalaman atau karakteristik dari seseorang atau kelompok orang yang menjadi subjek penelitian (responden). Sumber data dalam penelitian ini adalah data primer. Data primer merupakan data penelitian yang diperoleh secara langsung dari sumber yang asli. Data primer diperoleh dengan menggunakan daftar pertanyaan yang telah terstruktur dengan tujuan untuk mengumpulkan informasi dari para responden. Sumber data dari penelitian ini adalah score total yang diperoleh dari pengisian kuesioner yang telah disebarkan pada para responden. Teknik pengumpulan data dalam penelitian ini dengan menggunakan kuesioner atau daftar pernyataan terstruktur yang diajukan ke responden

Suatu hasil penelitian dapat dikatakan valid dan handal apabila data yang terkumpul menunjukkan keadaan yang sesungguhnya ada atau terjadi pada objek yang diteliti menggunakan instrumen yang handal. Untuk memastikan apakah instrumen yang digunakan dalam penelitian ini merupakan alat ukur yang akurat dan dapat dipercaya, maka digunakan uji validitas dan uji reliabilitas.

Sebelum melakukan pengujian regresi, terlebih dahulu dilakukan pengujian asumsi klasik yang berguna untuk mengetahui apakah data yang digunakan ketentuan dalam model regresi. Pengujian ini meliputi: 1) uji normalitas residual, dimana pengujian ini bertujuan untuk menguji apakah dalam model regresi residual berdistribusi normal 2) uji heteroskedastisitas, bertujuan untuk menguji apakah dalam regresi terjadi ketidaksamaan varians dari residual satu pengamatan ke pengamatan yang lain. 3) uji multikolinearitas, dimana pengujian ini bertujuan untuk memastikan apakah di dalam sebuah model regresi ada interkorelasi atau kolinearitas antar variabel bebas.

Uji kelayakan model menggunakan goodness of fit. Secara statistik, setidaknya goodness of fit dapat diukur dari nilai determinasi $\left(\mathrm{R}^{2}\right)$ dan uji F. Uji kelayakan model penelitian ini dilakukan dengan 
cara sebagai berikut: (1) Uji koefisien determinasi $\left(\mathrm{R}^{2}\right)$ pada intinya mengukur seberapa jauh kemampuan model dalam menerangkan variasi variabel terikat. Nilai koefisien determinasi adalah diantara nol dan satu. (2) Uji F, yaitu untuk menguji apakah model yang digunakan layak, digunakan uji $\mathrm{F}$ dengan menggunakan taraf signifikan $5 \%$.

\section{HASIL DAN PEMBAHASAN}

Analisis regresi linear berganda digunakan untuk mengetahui seberapa besar pengaruh faktor yang digunakan dalam model penelitian yaitu kepemimpinan transformasional dan kompensasi terhadap kinerja karyawan pada perusahaan BUMN di kota Padang. Dalam pengujian regresi diperoleh hasil sebagai berikut:

Tabel 1

Nilai Determinasi $\left(\mathbf{R}^{2}\right)$

Model Summary

\begin{tabular}{|l|r|r|r|r|}
\hline Model & $\mathrm{R}$ & $\mathrm{R}$ Square & $\begin{array}{c}\text { Adjusted R } \\
\text { Square }\end{array}$ & $\begin{array}{r}\text { Std. Error of } \\
\text { the Estimate }\end{array}$ \\
\hline 1 & $.855^{\mathrm{a}}$ & .732 & .723 & 1.90083 \\
\hline
\end{tabular}

a. Predictors: (Constant), Kompensasi_X2,

Kepemimpinan_Trans_X1

Berdasarkan tabel ditas, terlihat bahwa nilai Adjusted $R$ Square sebesar 0,723. Angka tersebut digunakan untuk melihat besarnya pengaruh keterlibatan variabel bebas terhadap variabel terikat sebesar 0,723 . Hal ini mengindikasikan bahwa keterlibatan variabel bebas terhadap variabel terikat adalah $72,3 \%$ sedangkan sisanya sebesar $72,7 \%$ dipengaruhi oleh faktor lain yang tidak diteliti dalam penelitian ini.

Untuk melihat ada atau tidaknya pengaruh variabel bebas secara bersama-sama terhadap variabel terikat serta untuk menguji apakah model yang digunakan sudah fix atau tidak patokan yang digunakan adalah membandingkan nilai signifikansi $\mathrm{F}(\alpha=0,05)$. Hasil uji $\mathrm{F}$ dapat dilihat dibawah ini:

Tabel 2

Hasil Uji F Statistik

ANOVA $^{\mathrm{b}}$

\begin{tabular}{|c|c|c|c|c|c|c|}
\hline \multicolumn{2}{|c|}{ Model } & $\begin{array}{l}\text { Sum of } \\
\text { Squares }\end{array}$ & $d f$ & $\begin{array}{l}\text { Mean } \\
\text { Square }\end{array}$ & $F$ & Sig. \\
\hline 1 & $\begin{array}{l}\text { Regressio } \\
\mathrm{n}\end{array}$ & 611.122 & 2 & 305.561 & 84.569 & $.000^{\mathrm{a}}$ \\
\hline & Residual & 224.016 & 62 & 3.613 & & \\
\hline & Total & 835.138 & 64 & & & \\
\hline
\end{tabular}

a. Predictors: (Constant), Kompensasi_X2,

Kepemimpinan_Trans_X1

b. Dependent Variable:

Kinerja_Karyawan_Y 
Berdasarkan tabel diatas, terlihat bahwa nilai signifikansi sebesar $0,000<0,05$. Nilai $\mathrm{F}_{\text {statisik }}>$ $\mathrm{F}_{\text {tabel, }}$, dimana $84.569>2.75$. Hal ini berarti kerangka atau model yang digunakan dalam penelitian ini sudah fix sehingga dapat dilanjutkan dengan pengujian secara parsial.

Pengujian hipotesis dilakukan membandingkan (a) thitung dengan tabel nilai sig dengan $\alpha=0,05$. Hipotesis diterima jika $t_{\text {hitung }}>\mathrm{t}_{\text {tabel }}$ dan nilai sig $<\alpha 0,05$. Berdasarkan uji t yang dilakukan maka diperoleh hasil pada tabel di bawah ini:

Tabel 3

Hasil Uji t Statistik

Coefficients $^{\mathrm{a}}$

\begin{tabular}{|c|c|c|c|c|c|c|}
\hline \multirow{2}{*}{\multicolumn{2}{|c|}{ Model }} & \multicolumn{2}{|c|}{$\begin{array}{l}\text { Unstandardized } \\
\text { Coefficients }\end{array}$} & \multirow{2}{*}{\begin{tabular}{|c|}
$\begin{array}{c}\text { Standardized } \\
\text { Coefficients }\end{array}$ \\
Beta \\
\end{tabular}} & \multirow[b]{2}{*}{$t$} & \multirow[b]{2}{*}{ Sig. } \\
\hline & & B & Std. Error & & & \\
\hline \multirow[t]{3}{*}{1} & (Constant) & 4.454 & 3.485 & & 1.278 & .206 \\
\hline & $\begin{array}{l}\text { Kepemimpinan_Trans } \\
\text { X1 }\end{array}$ & .392 & .069 & .508 & 5.662 & .000 \\
\hline & Kompensasi_X2 & .552 & .117 & .424 & 4.727 & .000 \\
\hline
\end{tabular}

a. Dependent Variable:

Kinerja_Karyawan_Y

Berdasarkan tabel diatas, pengujian hipotesis 1 dilakukan dengan membandingkan nilai thitung dan $t_{\text {tabel }}$ pada $\alpha=0,05$. Nilai $t_{\text {tabel }}$ adalah 1,997. Untuk variabel kepemimpinan transformasional $\left(\mathrm{X}_{1}\right)$ nilai thitung adalah 5,662 dengan nilai signifikansi 0,000 dan koefisiennya positif sebesar 0,392. Dengan demikian dapat dikatakan bahwa nilai $t_{\text {hitung }}>t_{\text {tabel, }}$, yaitu 5,662 >1,997 dan nilai signifikansi 0,000 < 0,05 . Hal ini menunjukkan bahwa kepemimpinan transformasional berpengaruh signifikasn positif terhadap kinerja manajerial. Sehingga hipotesis pertama dalam penelitian ini diterima.

Pengujian hipotesis 2 dilakukan dengan membandingkan nilai $t_{\text {hitung }}$ dan $t_{\text {tabel }}$ pada $\alpha=0,05$. Nilai $t_{\text {tabel }}$ adalah 1,997. Untuk variabel kompensasi $\left(X_{2}\right)$ nilai $t_{\text {hitung }}$ adalah 4,727 dengan nilai signifikansi 0,000 dan koefisiennya positif sebesar 0,552. Dengan demikian dapat dikatakan bahwa nilai $\mathrm{t}_{\text {hitung }}>\mathrm{t}_{\text {tabel, }}$, yaitu 4,727 $>1,997$ dan nilai signifikansi $0,000<0,05$. Hal ini menunjukkan bahwa kompensasi berpengaruh signifikan positif terhadap kinerja manajerial. Sehingga hipotesis kedua dalam penelitian ini diterima.

\section{KESIMPULAN DAN SARAN}

Kesimpulan yang dapat diambil dari pengaruh kepemimpinan transformasional dan kompensasi terhadap kinerja karyawan adalah:

1. Kepemimpinan transformasional berpengaruh signifikan positif terhadap kinerja karyawan

2. Kompensasi berpengaruh signifikan positif terhadap kinerja karyawan

Seperti kebanyakan kepemilikan lainnya, peneliti ini memiliki keterbatasan dimana data penelitian berasal dari responden yang disampaikan secara tertulis dengan bentuk kuesioner mungkin akan mempengaruhi hasil penelitian. Karena persepsi responden yang disampaikan belum tentu mencerminkan keadaan yang sebenarnya (subjektif) dan akan berbeda apabila data diperoleh melalui wawancara.

Berdasarkan keterbatasan yang telah diuraikan diatas, maka penulis mencoba untuk memberikan saran-saran sebagai berikut:

1. Bagi BUMN, khususnya bagi manajer disarankan untuk dapat memperhatikan kepemimpinan transformasional sehingga dapat meningkatkan kinerja karyawan. 
2. Perusahaan disarankan untuk memberikan kompensasi yang lebih kepada karyawan baik berupa kompensasi finansial maupun kompensasi non finansial karena dapat meningkatkan kinerja karyawan.

3. Bagi penelitian selanjutnya, diharapkan dapat memperluas daerah penelitian, atau dengan melakukan perubahan sampel penelitian sehingga hasil penelitian memungkinkan untuk disimpulkan secara secara umum serta dilakukan dalam alternatif jawaban.

4. Penelitian selanjutnya sebaiknya dapat mempertimbangkan faktor kondisional yang lain selain kepemimpinan transformasional dan kompensasi.

\section{DAFTAR PUSTAKA}

Basri, A.F.M. \& Rivai, V. 2005. Performance Appraisal. Jakarta: Raja Grafindo Persada.

Hasibuan, Malayu. 2012. Manajemen Sumber Daya Manusia. Jakarta: PT Bumi Aksara

Kesuma, I Gede Anggi Wira \& I Wayan Gede Supartha. "Penguruh Kepemimpinan Transformasional terhadap Komitmen Organisasional dengan Mediasi Organizational Behavior dan Kepuasan Kerja ”. E-Jurnal Manajemen Unud. Vol. 5 No. 6

Logahan, M. Jerry dkk. 2012. "Analisis Pengaruh Lingkungan Kerja dan Pemberian Kompensasi terhadap Kinerja Karyawan CV MUM Indonesia”. Binus Business $\quad$ Review. Vol. 3 No.1 Mei 2012: 573-586.

Mangkunegara, A. P. 2010. Evaluasi Kinerja SDM. Bandung: PT Refika Aditama

Mamik. 2010. "Pengaruh Gaya Kepemimpinan, Motivasi Kerja dan Komitemn Organisasi terhadap Kinerja Karyawan. “Jurnal Ekonomi”. Vol. XX (1)

Novitasari, Putri \& Budhi Satriyo. 2016. "Pengaruh Gaya Kepemimpinan Transformasional dan Motivasi Kerja terhadap Kinerja Karyawan”. Jurnal Ilmu dan Riset Manajemen. Vol. 5, Nomor 9, September 2016

Rai, Gusti Agung. 2008. Audit Kinerja pada Sektor Publik. Jakarta: Salemba Empat

Robbins, Stephen P. 2008. Perilaku Organisasi. Jakarta: PT Indeks

Sari, Evi Liana. 2015. "Pengaruh Pemberian Kompensasi terhadap Produktivitas Kerja Karyawan pada PT Ryan Jaya Persada". Jurnal Ilmu dan Riset Manajemen. Vol.4, Nomor 12

Simamora. H. 2006. Manajemen Sumber daya Manusia. Jakarta: Gramedia Pustaka Utama

Syaiin, Subakti. 2008. "Pengaruh Kepuasan Kerja Terhadap Kinerja”. Skripsi USU

Tjiptono, F. 2006, Manajemen Pelayanan Jasa. Yogyakarta: Penerbit Andi 